\title{
The effect of 6-weeks competition period training on body composition of boxers
}

\author{
Melike Nur AKGUL, Oktay CAKMAKCI \\ Faculty of Sport Sciences, Selçuk University, Konya, Turkey. \\ Address correspondence to M. N. Akgul, e-mail: melikenurakgul42@gmail.com
}

\begin{abstract}
The aim of this study to investigate the effects of 6-weekscompetition period training on body composition of elite boxers. In this study, 9 elite boxers from the boxing team of the Selçuk University volunteered. Subjects were of mean age $24.11 \pm$ 4.14 years, the experience of training $7.11 \pm 3.06$ years and height $179.12 \pm 6.72 \mathrm{~cm}$. Boxing training of the competition period was conducted for 6-weeks. The effects of the competition period training on body composition were evaluated as related to pre- and post-test data. Tanita TBF-410 Body Composition Analyzer was used to determine the parameters of subjects' body composition [VA $(\mathrm{kg})$, BMI $\left(\mathrm{kg} / \mathrm{m}^{2}\right)$, BMR (kcal), FAT (\%), FMASS $(\mathrm{kg})$, FFM $(\mathrm{kg})$, TMV $(\mathrm{kg})$ ]. For data analyses, SPSS 22.0 statistical package program was operated. Mean and standard deviation were computed. According to tests of normality, the Independent $t$-test was used to compare paired groups. The level of statistical significance was set at 0.05 . When the pre-test and post-test parameters were compared, body weight and BMI in pre-test were lower than post-test $(p<0.05)$. No significant difference between pre-test and post-test for BMR, FAT, FMASS, and TMW ( $>0.05)$. In conclusion, the recent study suggests that a 6-weeks training of competition period in elite boxers might decrease body weight and BMI but it might not have any effect on other parameters.
\end{abstract}

Keywords: Body composition, Boxer, competition period.

\section{INTRODUCTION}

Sportive competitions, including the boxing, complete the young regeneration's educational method and lead the society to have a healthy and dynamic life with regulation and continuity. In sports, competitions, for the boxers and as well as theater athletes, are the objective and realistic assessment factor of their technical situation and capacity of that raining they do (7).

Even when the person is at rest, s/he consumes a certain amount of energy for chemical activities in his body (10). The basal metabolic rate (BMR) is expressed as the lowest amount of energy required to sustain one's vital functions (9). The Resting Metabolic Rate (RMR) specifies the amount of calories the body can spend in resting position without any physical activity for 24 hours $(10,18)$. The basal metabolic rate (BMR) is used for the basal energy requirement, and the RMR is used for the resting energy requirement. The basal metabolism rate value is very low in relation to the RMR value (10).
Regular exercise programs change body compositions. Cardiorespiratory and weight trainings reduce the body weight. There are many studies on the effect of aerobic endurance training on body composition $(8,11)$.

Boxing sport takes place in the branches that require the most body contact and body fight with its style. As a result of boxing trainings, from physical and physiological characteristics, major changes are seen in aerobic power, muscle strength and endurance, flexibility, hand-eye coordination, foot games, quickness and reflexes (16). Boxing has a complex structure due to its dynamic and static characteristics at a high level and is among the fighting sports that require high level of power (13).

\section{MATERIALS \& METHODS}

In this research, the average age of 19-25, 9 male boxer at elite level participated as a volunteer subject in Selçuk University Physical Education and Sports High School. At the beginning of the study, the ethics committee report was obtained and each of the subjects was given detailed information about the 
risks and discomforts related to the study and the voluntary consent form was read and signed.

Height lengths of the athletes; The measurement was taken in 'cm' with a stadio meter (Holtain Ltd., $\mathrm{UK})$ measuring $\pm 1 \mathrm{~mm}$ after the overhead table is positioned so it will touch the vertex point at the position of anatomic ridge, bare foot, foot heels combined, holding the breath, head in the frontal plane. The subjects were taken in 'kg' with Tanita (Tanita 401A, Japan), which measures body mass index with a sensitivity of \pm 100 gr only with shorts, bare feet and anatomic posture. The measurements were made before and after the 6-week boxing training program. The Tanita tool provided us with the following data;

- Body weight VA (kg), BMI kg/m² / Body mass index

- BMR kj-kcl / Amount of energy needed by metabolism

- $\mathrm{FAT} \%$ : Fat rate

- FM kg / Body Fat Weight (kg)

- FFM kg / Fat-free body weight

- TBW kg / Water weight

\section{Training Schedule}

Boxing training in the competition period is applied for the first 4 weeks, 6 days a week for the last two weeks, 5 days a week.

Sparing; free combat training closest to the competition.

Condition; bag, sparing, free weight and running.
Technical Work; glove trainings with partner.

\begin{tabular}{ccc}
\hline \multicolumn{3}{c}{ Competition Training Program (6 weeks) } \\
\hline $20 \%$ Special & $40 \%$ Technical & $40 \%$ Tactics and \\
Condition & Works & Matches (Sparing) \\
\hline
\end{tabular}

\section{Statistical Analysis}

SPSS 22 IBM statistical package program was used for evaluation and calculation of data. Data are summarized by giving average and standard deviations. According to the comparison of normality order of the obtained data in pre-test and post-test, $t$ test (Paired t-test) was used in dependent groups. The significance level in this study was evaluated as $p$ $<0.05$.

\section{RESULTS}

Table 1. Individual characteristics of the boxers participating in the study

\begin{tabular}{ccccc}
\hline Variables & Age (yr) & $\begin{array}{c}\text { Sports } \\
\text { Age }(\mathrm{yr})\end{array}$ & $\begin{array}{c}\text { Height } \\
(\mathrm{cm})\end{array}$ & $\begin{array}{c}\text { Weight } \\
\text { Category }(\mathrm{Kg})\end{array}$ \\
\hline 1 & 19 & 6 & 170 & 56 \\
2 & 25 & 10 & 178 & 60 \\
3 & 20 & 4 & 178 & 75 \\
4 & 31 & 11 & 185 & 91 \\
5 & 26 & 4 & 190 & +91 \\
6 & 25 & 5 & 177 & 71 \\
7 & 19 & 10 & 185 & 81 \\
8 & 28 & 10 & 180 & 60 \\
9 & 24 & 4 & 170 & 71 \\
\hline
\end{tabular}

Table 2. Body composition in boxers participating in the study pre-test individual data.

\begin{tabular}{cccccccc}
\hline $\begin{array}{c}\text { Variables } \\
\text { (Pre-test) }\end{array}$ & VA $(\mathrm{kg})$ & BMI (Kg/m2) & BMR $(\mathrm{kcal})$ & FAT $(\%)$ & FMASS $(\mathrm{kg})$ & FFM $(\mathrm{kg})$ & TBW $(\mathrm{kg})$ \\
\hline 1 & 58.5 & 20.2 & 1655 & 4.1 & 2.4 & 56.1 & 41.1 \\
2 & 61.6 & 19.4 & 1672 & 6.3 & 3.9 & 57.7 & 42.2 \\
3 & 77.5 & 24.5 & 2049 & 10 & 8.2 & 69.3 & 50.7 \\
4 & 91.5 & 26.7 & 2278 & 15.2 & 13.9 & 77.6 & 56.8 \\
5 & 110 & 30.5 & 2642 & 20.5 & 22.6 & 87.5 & 64.1 \\
6 & 73.9 & 23.6 & 1897 & 12.2 & 9 & 64.9 & 47.5 \\
7 & 88.9 & 26 & 2326 & 12.5 & 11.1 & 77.8 & 57 \\
9 & 62.4 & 19.3 & 1602 & 11.7 & 7.3 & 55.1 & 40.3 \\
\hline
\end{tabular}


Table 3. The body composition of the athletes participating in the study the final test individual.

\begin{tabular}{cccccccc}
\hline $\begin{array}{c}\text { Variables } \\
\text { (Final test) }\end{array}$ & BW $(\mathrm{kg})$ & BMI (Kg/m2) & BMR $(\mathrm{kcal})$ & FAT $(\%)$ & FMASS $(\mathrm{kg})$ & FFM $(\mathrm{kg})$ & TBW $(\mathrm{kg})$ \\
\hline 1 & 56.7 & 19.6 & 1622 & 3 & 1.7 & 55 & 40.3 \\
2 & 60 & 18.9 & 1640 & 5.7 & 3.4 & 56.6 & 41.4 \\
3 & 76.7 & 24.2 & 2059 & 9 & 6.9 & 69.8 & 51.1 \\
4 & 86.6 & 25.3 & 2207 & 12.6 & 10.9 & 75.7 & 55.4 \\
5 & 107.7 & 29.8 & 2567 & 20.9 & 22.5 & 85.2 & 62.4 \\
6 & 74.6 & 23.8 & 1950 & 10.3 & 7.7 & 66.9 & 49.9 \\
7 & 86.8 & 25.4 & 2277 & 12.1 & 10.5 & 76.3 & 55.9 \\
9 & 62.9 & 19.4 & 1583 & 13.8 & 8.7 & 54.2 & 39.7 \\
\hline
\end{tabular}

Table 4. Average values of the characteristics of boxers participating in the study.

\begin{tabular}{lccc}
\hline Variables & N & Mean & SD \\
\hline Age (yr) & 9 & 24.11 & 4.137 \\
Sports age $(\mathrm{yr})$ & 9 & 7.11 & 3.060 \\
Boy $(\mathrm{cm})$ & 9 & 179.22 & 6.72 \\
\hline
\end{tabular}

Table 5. Body composition average values for the participating athletes.

\begin{tabular}{lccc}
\hline \multirow{2}{*}{ Variables } & Pre-test & & Final-test \\
\cline { 2 - 2 } & Mean \pm SD & & Mean \pm SD \\
\hline BW $(\mathrm{kg})$ & $77.51 \pm 16.79$ & & $76.07 \pm 16.00$ \\
BMI $(\mathrm{kg} / \mathrm{m} 2)$ & $23.92 \pm 3.76$ & & $23.47 \pm 3.57$ \\
BMR $(\mathrm{kcal})$ & $1996.0 \pm 356.8$ & & $1968.7 \pm 339.0$ \\
FAT $(\%)$ & $11.88 \pm 4.84$ & & $11.39 \pm 5.26$ \\
FMASS $(\mathrm{kg})$ & $9.89 \pm 5.94$ & & $9.26 \pm 5.94$ \\
FFM $(\mathrm{kg})$ & $67.63 \pm 11.30$ & & $66.81 \pm 10.88$ \\
TMW $(\mathrm{kg})$ & $49.51 \pm 8.29$ & & $50.02 \pm 7.99$ \\
\hline
\end{tabular}

Table 6. Comparison of pre-test and post-test values of body composition of athletes participating in the study.

\begin{tabular}{lcccc}
\hline Variables & Mean & SD & $\mathrm{t}$ & $\mathrm{p}$ \\
\hline BW $(\mathrm{kg})$ & 1.44 & 1.68 & 2.578 & $0.033^{*}$ \\
BMI $\left(\mathrm{Kg} / \mathrm{m}^{2}\right)$ & 0.46 & 0.472 & 2.896 & $0.020^{*}$ \\
BMR $(\mathrm{kcal})$ & 27.33 & 39.73 & 2.064 & 0.073 \\
FAT $(\%)$ & 0.49 & 1.42 & 1.037 & 0.330 \\
FMASS $(\mathrm{kg})$ & 0.63 & 1.23 & 1.551 & 0.159 \\
FFM $(\mathrm{kg})$ & 0.82 & 1.31 & 1.881 & 0.097 \\
TMW $(\mathrm{kg})$ & -0.51 & 3.13 & -0.489 & 0.638 \\
\hline${ }^{*} \mathrm{P}<0.05$ & & & &
\end{tabular}

When the Table 6 was examined, the comparison of pre-test and post-test values for body composition of the athletes participating in the study was found to be significant lower than the pre-test values of body weight and BMI end-test values $(\mathrm{P}<0.05)$. There is no statistically significant difference in BMR, FAT, FMASS, FFM and TMW pre-test values compared to post-test values $(\mathrm{P}>0.05)$.

\section{DISCUSSION}

The literature shows the average height; Azerbaijan Boxing National Team average height $163.30 \mathrm{~cm}$ (3), Turkish Boxing National Team average $174.40 \mathrm{~cm}$ (15), average height of Turkish Boxing National Team $177.46 \mathrm{~cm}$, average weight of Ukrainian Boxing National Team $178.07 \mathrm{~cm}$ (5), and average height in the Georgia National Boxing Team is $180.11 \mathrm{~cm}$ (4). Findings were between $163.30-$ $180.11 \mathrm{~cm}$ and our study was found to be $179.22 \pm 6.72$ $\mathrm{cm}$. In weight category sports, such as boxing, it is usual to see individual and team differences.

During the six week training session in there search group: Body weight $(\mathrm{kg})$ was found to be $77.511 \pm 16.788$ in the pretest, $76.067 \pm 15.999$ in the final test and it was determined that the body weight final-test values were significantly lower than the pre-test values $(\mathrm{P}<0.05)$.

Çınar et al. (4) found that the average body weight of the Turkish National Boxing Team was $71.91 \mathrm{~kg}$, the average body weight of the Ukrainian Boxing National Team was $72.72 \mathrm{~kg}$, and the average body weight of Çakmakcı (4) Georgia Boxing National Team was $70.73 \mathrm{~kg}$. It can be assumed that the difference between this study finding and the literature information can be due to the body weight of the boxers in the different weight category (14). In Turkish National Team Boxers, pre-camp body weight values were found to be $67.44 \mathrm{~kg}$ and later $68.44 \mathrm{~kg}$. The final test values were high and 
significant compared to the pre-test. In this study finding, in the pre- and post-test values, the post-test values decreased significantly compared to the pretest values. Although there is a contrast between these two studies, it should be a practical result (14). Post-camp values are higher and more significant than pre-camp values because the intensity of nutrition is high during camping work before the European Championship preparations, the matches are away from a future date and the boxers are away from weight gain. This study was carried out during training sessions before the tournament. In this context, a significant reduction in post-test values may be attributed to the importance of balanced nutrition, close-up competition date and weight control. It can be said that differences in the body weight averages as a team are generally due to the heavyweight (+91) athletes included in the study group in the sports such as boxing.

When the BMI values reexamined; Çınar et al. (5) determined the average values of boxers of Turkish and Ukrainian Boxing National Team as $22.83\left(\mathrm{~kg} / \mathrm{m}^{2}\right)$ and $21.66\left(\mathrm{~kg} / \mathrm{m}^{2}\right)$, respectively. Pala \& Savucu (15) found that the average Turkish BKI $22.11\left(\mathrm{~kg} / \mathrm{m}^{2}\right)$ before the final preparatory camp and before the European championship and the average post-camp BKI was $22.19(\mathrm{Kg} / \mathrm{m} 2)$. He reported the there was no significant difference between the average values of obtained BMI before and after the camp ( $\mathrm{P}>0.05)$. As a matter of fact, this study is similar to the research in respect to BMI levels and for the competition period. In the study; for boxers, the BMI pre-test was determined as $23.922 \pm 3.755(\mathrm{Kg} / \mathrm{m} 2)$ and the final test was determined as $23.467 \pm 3.570(\mathrm{Kg} / \mathrm{m} 2)$. BMI post-test values were found to be significantly lower than pre-test values $(\mathrm{P}<0.05)$. It can be said that the difference between the studies is due to the contents of the training. In addition to this, the significance of the pre- and post-test is as follows: In this study, it can be said that the findings for the boxers depends on the competition period trainings (14).

In the research of study group composed of university students, Arabaci et al. (2) found BMR $1865 \pm 314 \mathrm{Kcal} /$ day in male students $(\mathrm{n}=574)$ with an average age of $22.3 \pm 1.9$ years. Alpay et al. (1) found that the Basal Metabolic Ratio (kcal) between the group (n 31) and the group without the weight loss (n 38) $2167.16 \pm 407.96$ and $2001.453 \pm 07.16$, respectively, and it was found that there were no statistically significant differences. In this study for university boxers BMR (kcal) pretest was $1996.000 \pm$ 356.765 , final test was $1968.667 \pm 339.034$ determined as an average. No statistically significant difference was found between pretest values and posttest values $(\mathrm{P}>0.05)$.

Pala \& Savucu (15), determined the Turkish Boxing National Team's body fat ratio values before the European Championship 12.32 (\%), after the championship 12.33 (\%).It was reported there was no significant difference between pre- and post-test values. The results are similar in both numerical and change levels. In both studies the training content and duration should be similar. The obtained results for competition and the similar researches increasing the importance of research. Therefore, it is seen that the training programs for competition do not have a significant change in body fat percentage and they are over-the-top anaerobic weight in boxing and high performance sports.

In studies conducted at the level of national teams; the average body fat ratio of the Ukrainian Boxing National Team was $13.40 \%$ (5), the average body fat ratio of Azerbaijan Boxing National Team was found to be $10.29 \%$ and the average body fat ratio of Turkish Boxing National Team was found to be $13.16 \%$ (3). Body fat percentage (\%) in university boxers determined $11.878 \pm 4.840$ in pre-test and $11.389 \pm 5.264$ in final test. No statistically significant difference was found between pretest values and posttest values $(\mathrm{P}>0.05)$. While our study finds parallel with the findings of Pala (14), numerical differences between literature information values; depend on the nutrition, camping period, competition period.

Kaya \& Özçelik (12) determined FM (kg) values by dividing 714 male students into two age groups.409 male students with an average age of 1418 years of $15.6 \pm 0.05$ years found the fat tissue as 6.85 \pm 0.2 .305 male students with an average age range of 19-23 years (21.4 \pm 0.1 years) found an average fat tissue average of $8.63 \pm 0.2$.In a study of elite Taekwondo athletes FM (kg) was found to be $4.8 \pm 3.6$ $\mathrm{kg}$ (2). Sarıkavak et al. (17), sportsmen from the different sports branches and respectively; $9.69 \pm 0.70$ for the football player, $9.74 \pm 1.65$ for the handball player, $6.94 \pm 0.94$ for the athlete, and $7.49 \pm 1.05 \mathrm{FM}$ $(\mathrm{kg})$ for the cross-country skiing values determined.

In the study of Kaya \& Özçelik (12), 714 male students divided into two age groups and determined the FFM values. In 409 male students who were between $14-18$ years $(15.6 \pm 0.05)$ years, found the fat-free tissues as $51.23 \pm 0.3$ and 305 male students who were between 19-23 years of age (21.4 \pm 
0.1 ) years found the average fat-free tissues as $59.69 \pm$ $0.3 \mathrm{~kg}$. Arabaci et al. (2) reported that the mean value of FFM (kg) in elite Taekwondo athletes was $58.4 \pm$ 8.3 , while the mean value of FFM $(\mathrm{kg})$ in super league male handballs was $75.2 \pm 6.4$. Sarıkavak et al. (17) evaluated the mean FFM $(\mathrm{kg})$ values for the elite athletes respectively; football player $65.23 \pm 1.42$, handball player $62.11 \pm 2.62$, athlete $57.01 \pm 1.96$ and cross-country skiers $58.32 \pm 2.13$.

In the literature information, Kaya \& Özçelik (12) showed the lowest values with $51.23 \pm 0.3$, and Arabac1 et al. (2) gave the highest FFM (kg) mean values with 75.2 \pm 6.4.In that research FFM $(\mathrm{kg})$ pretest was $67.633 \pm 11.296$ and post-test was $66.811 \pm$ 10.875 in university boxers. There was no statistically significant difference between pretest values and posttest values $(\mathrm{P}>0.05)$. The finding is in the lowesthighest range.

Demirkan et al. (6) conducted a study using the Tanita Body Composition Analyzer BC-418 method, for body fluid mass detection in elite wrestlers. Wrestling participates in national team selection; TVS (kg) $51.6 \pm 8.5$ for selected wrestlers and TVS (kg) 54.0 \pm 9.2 values determined for unselected wrestlers. Using a similar method by Arabac1 \& (2), Taekwondo atlethe's at the elite level also found body fluid mass $(\mathrm{kg})$ as $42.7 \pm 6.1$.In the study; for boxers, TMW $(\mathrm{kg})$ pre-test was $49.511 \pm 8.288$ and post-test was $50.022 \pm$ 7.985 with the same method. No statistically significant difference was found between pretest values and posttest values $(\mathrm{P}>0.05)$. The change in the averages of total body water values can be attributed to the fact that the research groups are from different sports branches and differences in the body muscle mass.

As a result, it has been determined that the 6week competition period applied to elite boxers does not affect the body weight parameters and other body composition parameters but body weight and BKI significantly affected.

\section{REFERENCES}

1. Alpay CB, Ersöz Y, Karagöz Ş, Oskoueı MM. Elit güreşçilerde müsabaka öncesi ağırlık kaybı, vücut kompozisyonu ve bazı mineral seviyelerinin karşılaştırılması. International Journal of Science Culture and Sport, 2015; (Special Issue 4): 338-348.

2. Arabacı R, Erden S, Korkmaz NH, Çankaya, Korkmaz K. Üniversite öğrencilerinin fiziksel aktiviteleri, beslenme alışkanlıkları ve vücut kompozisyonları arasındaki ilişkinin araştırılması. Niğde Üniversitesi Beden Eğitimi ve Spor Bilimleri Dergisi, 2012; 6(3): 234-343

3. Beyleroğlu M. Türkiye ve Azerbaycan a milli boks takımlarının antropometrik ve fiziksel yapılarının karşılaştırılması. Sakarya Üniversitesi Sosyal Bilimler Enstitüsü Yayınlanmamış Yüksek Lisans Tezi, Sakarya, 1998.

4. Çakmacı O, Fişekçioğlu B, Çumralıgil B, Patlar S, Çınar V. Türkiye ve Gürcistan a milli boks takımlarının bazı fiziksel özelliklerinin karşılaştırılması. Atatürk Ünv. Beden Eğitimi ve Spor Bilimleri Dergisi, 2005; 3: 1-5.

5. Çınar V, Biçer Y, Pala R, Savucu Y, 2009. Türk ve Ukrayna boks milli takımının bazı fiziksel uygunluk değerlerinin karşılaştırılması. E-Journal of New World Sciences Academy, 2009; 4(3): 154-161.

6. Demirkan E, Kutlu M, Koz M, Ünver R, Bulut E. Elit güreşçilerde vücut kompozisyonu ve hidrasyon değişimlerinin incelenmesi, Selçuk Üniversitesi Beden Eğitimi ve Spor Bilimleri Dergisi, 2012; 14(2): 179-183

7. Erkuyumcu G. Boks Hakemliği. İstanbul: Polat Ofset, 1988.

8. Galliven EA, Singh A, Michelson D. Hormonal and metabolic responses to exercise across time of day and menstrual cycle phase. J Appl Physiol, 1997; 85: 1822-1831.

9. Ganong WF. Tibbi Fizyoloji. 20. Baskı, İstanbul: Nobel Tip Kitabevleri, 2002.

10. Guyton AC, Hall JE. Textbook of Medical Physiology. 11th Ed. Philadelphia, 2006.

11. Kannin B, Phil D. The effect of short- vs. long- bout exercise on mood, $\mathrm{VO}_{2 \mathrm{max}}$, and percent body fat. Preventive Medicine 2005; 40: 92-98.

12. Kaya H, Özçelik O. Vücut bileşimlerinin değerlendirilmesinde vücut kitle indeksi ve biyoelektrik impedans analiz metodlarının etkinliğinin yaş ve cinsiyete göre karşılaştırılması. F Ü Sağ Bil Tıp Derg, 2009; 23(1): 1-5.

13. Mitchell H, Willams L, Reter BR. Clasification of sports medicine and science in spots and exercise. American College of Sports Medicine and the American College of Cardiology, 1999.

14. Pala R. Boks milli takımının avrupa şampiyonasına hazırlık kampları süresince bazı fiziksel ve oksidatif stres parametrelerinin incelenmesi. Doktora Tezi, Frrat Üniversitesi Sağlık Bilimleri Enstitüsü, Beden Eğitimi Ve Spor Anabilim Dalı, Elazığ, 2011.

15. Pala R, Savucu Y. Boks milli takımının avrupa şampiyonasına hazırlık kampları süresince bazı fiziksel ve oksidatif stres parametrelerinin incelenmesi. Fırat Ünv Sağlık Bil Tıp Der, $2011 ; 25 ; 3: 115-120$.

16. Quinna. Knockout Training Tips. United States Profession Tenis Registry, USA, 1994.

17. Sınırkavak G, Dal U, Çetinkaya Ö. Elit sporcularda vücut kompozisyonu ile maksimal oksijen kapasitesi arasindaki ilişki. C. Ü. Tıp Fakültesi Dergisi, 2004; 26(4): 171-176.

18. Vander AJ, Sherman JH, Luciano DS. Human Physiology: The Mechanisms of Body Function. 6th International Edition, USA, 1994. 